\title{
FENOMENA KEMISKINAN DI KOTA MAKASSAR DAN UPAYA PENANGGULANGANNYA DALAM PERSPEKTIF EKONOMI ISLAM
}

\author{
Oleh: \\ Emily Nur Saidy, dan Nurul Hidayah \\ UIN Alauddin Makassar \\ e-mail: emilynurs@gmail.com dan nurulhidaya95@gmail.com
}

\begin{abstract}
ABSTRAK
Tujuan dari penelitian ini adalah untuk mengetahui fenomena kemiskinan yang terjadi di Kota Makassar ditinjau dalam perspektif ekonomi Islam serta untuk mengetahui upaya yang dilakukan pemerintah dalam menanggulangi kemiskinan yang terjadi di kota Makassar. Penelitian ini bersifat kualitatif dengan pendekatan fenomenologis dan pendekatan normatif. Hasil penelitian menunjukkan bahwa urbanisasi merupakan salah satu penyebab bertambahnya jumlah penduduk miskin di perkotaan. Bertambahnya jumlah penduduk di kota Makassar yang tidak dibarengi dengan peningkatan lapangan pekerjaan sehingga menimbulkan fenomena-fenomena seperti anak jalanan, pengemis dan geng motor di perkotaan. Dalam Islam, Rasulullah menganjurkan kita untuk berusaha dan mencari nafkah yang halal dan thoyyib, tidak mengerjakan sesuatu yang haram, dan tidak dengan meminta-minta. Dalam menanggulangi fenomena kemiskinan pemerintah kota Makassar memberikan suatu upaya dengan menjaga stabilitas harga bahan kebutuhan pokok, mendorong pertumbuhan yang berpihak pada rakyat miskin, menyempurnakan dan memperluas cakupan program pembangunan berbasis masyarakat, meningkatkan akses masyarakat miskin kepada pelayanan dasar, membangun dan menyempurnakan sistem perlindungan sosial bagi masyarakat miskin.
\end{abstract}

Kata Kunci: Kemiskinan; Pemerintah; Penduduk Perkotaan 


\section{PENDAHULUAN}

Kemiskinan merupakan permasalahan umum yang terjadi di negara berkembang tidak terkecuali di Indonesia. Kemiskinan adalah suatu keadaan yang menggambarkan kurangnya pendapatan untuk memenuhi kebutuhan pokok. Kebutuhan pokok dapat diartikan sebagai suatu paket barang dan jasa yang diperlukan oleh setiap orang untuk bisa hidup secara manusiawi. Terdiri dari sandang, pangan dan papan. ${ }^{1}$ Al-Ghazali mendefinisikan kemiskinan sebagai ketidakmampuan seseorang dalam memenuhi kebutuhan mereka sendiri baik dari segi kebutuhan material dan kebutuhan rohani. Argumen tersebut dapat juga dibuat oleh Ahmed, kemiskinan bukan hanya merupakan perampasan barang dan jasa, tetapi juga kurangnya kemiskinan dalam roh. ${ }^{2}$

Islam mengakui perbedaan si kaya dan si miskin, ada yang diberikan rezeki lapang dan ada pula yang dalam kondisi sempit (miskin). Miskin dan kaya dalam Islam merupakan suatu keniscayaan hidup. Seperti yang dijelaskan dalam QS. Al-Isra/ 17:30.

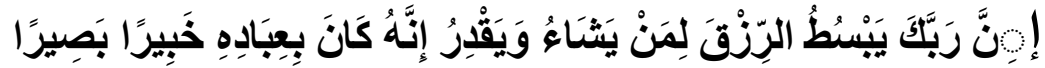

Terjemahnya:

"Sesungguhnya Tuhanmu melapangkan rezeki kepada siapa yang Dia kehendaki dan menyempitkannya; Sesungguhnya Dia Maha mengetahui lagi Maha melihat akan hamba-hamba-Nya."

Ayat ini menjelaskan bahwa adanya perbedaan perolehan harta yang berbeda antar umat manusia. Bentuk ungkapan ini tidak mempertentangkan antara yang kaya dengan miskin, atau lapang dengan sempit, adanya batasan

${ }^{1}$ Abu Ahmad, Ilmu Sosial Dasar (Jakarta: Renika Cipta, 2003), h. 344.

${ }^{2}$ Nurul Huda, dkk. Ekonomi Pembangunan Islam, (Jakarta: Prenadamedia Group, 2015), h.23.

${ }^{3}$ Departemen Agama RI, Al-quran dan Terjemahan, (Jakarta : WALI, 2013), h. 144 
antara si kaya dengan si miskin akan mengakibatkan adanya strata sosial yang terjadi di masyarakat jika dilihat dari pandangan ekonomi. Tentu saja batasan tersebut adalah bagi manusia yang mampu dalam mencari kesempatan kerja. Memiliki skill atau keterampilan sesuai dengan kerja, mau bekerja keras dan bersungguh-sungguh, tipe manusia yang seperti ini yang diberikan kelapangan rezeki oleh Allah Swt.

Kemiskinan bukan hanya terjadi di pedesaan tapi juga di perkotaan. Megahnya gedung pencakar langit di daerah perkotaan tidak menjamin akan kesejahteraan penduduknya realitanya selain gedung pencakar langit banyak juga kita jumpai rumah kumuh yang terdapat dipinggiran kota.

Urbanisasi merupakan salah satu penyebab bertambahnya penduduk miskin di perkotaan. Penduduk dari daerah pedesaan yang datang ke kota tanpa keahlian yang memadai untuk mendapatkan pekerjaan yang layak, hal ini tentu akan berdampak pada kurangnya penghasilan yang mereka terima tidak terkecuali di kota Makassar. Tingginya peluang lapangan kerja bagi masyarakat diluar kota menjadi penyebab utama bertambahnya jumlah penduduk Makassar. ${ }^{4}$ Sehingga bertambahnya penduduk di wilayah perkotaan membuat persaingan sangatlah terlihat jelas. Penjelasan ini dapat dipahami bahwa banyak faktor yang menyebabkan kemiskinan, meskipun demikian gerakan yang diarahkan untuk memberantas kemiskinan juga terus-menerus dilakukan oleh pemerintah seperti bantuan yang diberikan untuk mencukupi kebutuhan rakyat, membuka lapangan pekerjaan, serta bantuan modal sehingga hal tersebut mampu merubah nasib rakyatnya. Hal merupakan tanggung jawab pemerintah dalam mengatasi kemiskinan dan meningkatkan kesejahterakan bagi rakyatnya. Mengutip kata Khalifah Umar bin Khattab "Sebaik baik pemerintah ialah yang mensejahterakan rakyatnya, seburuk buruk pemerintah ialah yang menyengsarakan rakyatnya".

${ }^{4}$ Berita Sulsel, Data Penduduk Miskin Makassar 2015-2017, http://beritasulsel.com/2017/03/31 /data-jumlah-penduduk-makassar-tahun-2015-hingga-2017/ (26 Oktober 2017) 


\section{TINJAUAN TEORETIS}

\section{Pengertian Kemiskinan}

Kemiskinan adalah taraf hidup yang rendah atau suatu kondisi ketidakmampuan secara ekonomi untuk memenuhi standar hidup rata-rata masyarakatnya di suatu daerah. Kondisi ketidakmampuan ini di tandai dengan rendahnya kemampuan pendapatan untuk memenuhi kebutuhan pokok baik berupa pangan, sandang, maupun papan. Kemampuan pendapatan yang rendah ini juga akan berdampak berkurangnya kemampuan untuk memenuhi standar hidup rata-rata seperti standar kesehatan masyarakat dan standar pendidikan. ${ }^{5}$

Definisi tentang kemiskinan menurut Nabil Subhi Ath-Thawil adalah tiadanya kemampuan untuk memperoleh kebutuhan-kebutuhan pokok. Kebutuhan-kebutuhan ini di anggap pokok karena ia menyediakan batas kecukupan minimum untuk hidup manusia yang layak dengan tingkatan kemuliaan yang dilimpahkan Allah atas dirinya. ${ }^{6}$

Definisi kemiskinan dapat ditinjau dari tinjauan ekonomi, sosial dan politik. Secara ekonomi kemiskinan adalah kekurangan sumber daya yang dapat digunakan untuk meningkatkan kesejahteraan. Secara sosial kemiskinan diartikan kekurangan jaringan sosial dan struktur untuk mendapatkan kesempat an-kesempatan meningkatkan produktivitas. Sedangkan secara politik kemiskinan diartikan kekurangan akses terhadap kekuasaan. ${ }^{7}$

${ }^{5}$ Elly M. Setiadi, Usman Kolip, Pengantar Sosiologi, ( Jakarta : Prenamedia Group, 2011), h. 788

${ }^{6}$ Aath-Thawil, Kemiskinan dan Keterbelakangan di Negara-Negara Muslim, cet 1 Terjemahan Muhammad Bagi, (Bandung : Mizan, 1985), h.36

${ }^{7}$ Tadjuddin Noer Efendi, Sumber Daya Manusia, Peluang Kerja dan Kemiskinan, (Yogyakarta : Pustaka Pelajar, 1993), h. 201-204. 
Dari beberapa definisi diatas, kemiskinan adalah suatu kondisi ketidakmampuan sesorang adalan memenuhi kebutuhan dasar atau standar hidup (sandang, papan dan pangan) karena pendapatan yang rendah.

\section{Macam - Macam Kemiskinan}

Pertama, Kemiskinan Kultural adalah bentuk kemiskinan yang terjadi sebagai akibat adanya sikap dan kebiasaan seseorang atau masyarakat yang umumnya berasal dari budaya atau adat istiadat yang relatif tidak mau untuk memperbaiki taraf hidup dengan tata cara yang modern. Kebiasaan seperti ini dapat berupa sikap malas, pemboros atau tidak hemat, kurang kreatif, dan relatif pula bergantung pada pihak lain.

Kedua, Kemiskinan Natural adalah karena dari awalnya memang miskin. Kelompok masyarakat ini menjadi miskin karena tidak memliki sumber daya manusia maupun pembangunan. Kemiskinan natural ini merupakan kemiskinan yang di sebabkan oleh faktor-faktor alamiah seperti karena cacat, sakit, usia lanjut atau karena bencana alam. Kemiskinan ini merupakan daerah yang kritis sumber daya alamnya ataupun daerah yang terisolasi.

Ketiga, Kemiskinan Struktural adalah bentuk kemiskinan yang di sebabkan karena rendahnya akses terhadap sumber daya yang pada umumnya terjadi pada suatu tatanan sosial budaya ataupun sosial politik yang kurang mendukung adanya pembebasan kemiskinan. Bentuk kemiskinan seperti ini juga terkadang memiliki unsur diskriminatif. 8

\section{Faktor-Faktor Penyebab Kemiskinan}

Menurut pendapat Bagong Suyanto, ada tiga faktor penyebab terjadinya kemiskinan di pedesaan dan diperkotaan, yaitu :9 Pertama, Sempitnya penguasaan dan pemilikan lahan atau akses produksi lain, di tambah lagi

${ }^{8}$ Elly M. Setiadi, dan Usman Kolip, Pengantar Sosiologi, h. 796.

${ }^{9}$ Faisal Basri, Perekonomian Indonesia, (Jakarta : Erlangga, 2002), h.98. 
kurangnya ketersediaan modal yang cukup untuk usaha. Kedua, karena nilai tukar hasil produksi yang semakin jauh tertinggal dengan hasil produksi lain, termasuk kebutuhan hidup sehari-hari. Ketiga, Karena tekanan perangkat kemiskinan dan ketidaktauan masyarakat, dengan artian mereka terlalu relatif terisolalir atau tidak memiliki akses yang cukup untuk memperoleh informasiinformasi yang dibutuhkan, disamping itu masyarakat secara fisik lemah karena kurang gizi, mudah terserang penyakit dan tidak berdaya atau rentan.

\section{Kemiskinan di Perkotaan}

Kesejahteraan yang adil dan makmur adalah cita-cita semua bangsa, namun masih sedikit yang mampu mewujudkannya. Oleh karena itu pemberantasan kemiskinan masih merupakan salah satu agenda yang perlu segera di tuntaskan. Kesempatan kerja dengan tingkat penghasilan yang layak masih jauh di bawah jumlah angkatan kerja yang membutuhkanya, sehingga kelompok pengangguran dan setengah pengangguran makin meningkat di perkotaan. Kondisi seperti ini pada gilirannya juga akan meningkatkan angka kemiskinan.

Ukuran kemiskinan di setiap daerah bisa berbeda-beda. Ada yang melihat bahwa masyarakat atau orang miskin itu di lihat dari rendahnya pendapatan perbulan di bawah upah minimum reguler yang telah di tetapkan oleh pemerintah. Akan tetapi, ukuran tersebut, belum bisa di katakan tepat untuk menilai suatu ukuran kemiskinan. Bisa saja dalam suatu daerah ukuran orang miskin itu di lihat dari tidak sanggupnya dia memenuhi kebutuhan hidup sehari-hari, baik untuk dirinya maupun untuk keluarga. Ini di sebabkan banyaknya tanggungan dan beban hidup yang di beratkan kepada seseorang.

Urbanisasi merupakan salah satu faktor bertambahnya penduduk miskin di perkotaan. Mereka yang datang berbondong-bondong datang dari kampung halamanya untuk dapat bertahan hidup dengan mengadu nasib untuk mencari kehidupan yang lebih baik. Selain kota, yang di banjiri oleh para penduduk urban, terdapat juga penduduk asli kota tersebut. Kehidupan masyarakat di kota umumya memiliki mobilitas yang tinggi. 
Pembangunan secara tidak terduga memisahkan masyarakat menjadi dua kelompok yang berbeda tajam dari satu yang lain. Ada satu kelompok yang stabil, kuat ekonominya, terjamin masa depannya. Ada satu kelompok yang tidak stabil, mudah bergeser dari sektor yang lain, cepat berpindah pekerjaan. Kelompok inilah yang di sebut masa apung. ${ }^{10}$ Mereka adalah kelompok yang paling besar. Kehidupan ekonominya hanya berlangsung dari tangan ke mulut, semuanya habis untuk makan dan tidak terlibat dalam ekonomi pasar.

Daerah perkotaan sudah lama dipandang dengan daerah pedesaan yang di anggap terbelakangan dan belum maju. Orang kota "modern" dan kaum tani "tradisional", yang buta berita dan melek berita, karena pemilikan media sumberdaya insani dan sumberdaya benda, teknologi rendah versus teknologi tinggi, ekonomi subsistensi yang tidak produktif versus produksi padat modal untuk pasar, adalah serangkaian perbedaan yang di akui ada antara daerah perkotaan dan daerah perdesaan. ${ }^{11}$ Pesatnya pertumbuhan kota umumnya disebabkan kota migrasi, dan hal ini melahirkan suatu masyarakat kota yang sangat kompleks menurut ukuran kesukuan, pekerjaan serta kelompokkelompok sosial.

10Parsudi Suparlan, Kemiskinan di Perkotaan, (Jakarta : Yayasan Obor Indonesia, 1995), h.75

11Parsudi Suparlan, Kemiskinan di Perkotaan, h.76 


\section{METODE PENELITIAN}

\section{Jenis dan lokasi Penelitian}

Penelitian ini adalah jenis penelitian kualitatif deskriptif yaitu penelitian yang menggambarkan secara sistematik dan akurat fakta serta karakteristik mengenai populasi atau mengenai bidang tertentu. Penelitian ini dilakukan di Kantor Dinas Sosial yang berlamat di Jl. Arif Rahman Hakim No. 50, Ujung Pandang Baru, Tallo, Kota Makassar, Sulawesi Selatan. Pendekatan yang digunakan dalam penelitian ini adalah pendekatan fenomenologi. Peneliti dalam pandangan fenomenologis menurut Moleong berusaha memahami arti peristiwa dan kaitan-kaitannya terhadap orang-orang biasa dalam situasi tertentu. ${ }^{12}$ Selain Pendekatan fenomenologi, pendekatan normatif juga menjadi salah satu acuan dalam penelitian ini dimana pendekatan normatif melihat apakah sesuatu itu sesuai dengan syariat, benar ataukah salah sesuai dengan alQur'an dan Hadis. Adapun data yang digunakan dalam penelitian ini adalah data primer. Adapun metode pengumpulan data dalam penelitian ini adalah wawancara juga teknik dokumentasi. Metode analisis data yang digunakan adalah model Miles dan Hubermen dalam buku tersebut dijelaskan bahwa analisis data meliputi tiga alur kegiatan yaitu reduksi data, penyajian data dan penarikan kesimpulan 13

12Lexy J Meleong, Metodologi Penelitian Kualitatif, (Bandung : PT Remaja Rosdakarya, 1994) h.9.

${ }^{13}$ Moleong, Metode Penelitan Kualitatif, h.248. 


\section{HASIL PENELITIAN}

\section{Fenomena Kemiskinan di Kota Makassar dalam Perspektif Islam}

Urbanisasi merupakan salah satu penyebab bertambahnya jumlah penduduk miskin di perkotaan. Bertambahnya jumlah penduduk di kota Makassar yang tidak dibarengi dengan peningkatan lapangan pekerjaan sehingga menimbulkan fenomena fenomena seperti anak jalanan, pengemis dan geng motor di perkotaan. Fenomena kemiskinan yang terjadi di kota Makassar sangatlah memprihatinkan dan membutuhkan perhatian khusus dari pemerintah, dikarenakan banyak pemuda-pemudi di kota Makassar yang bekerja tidak sesuai dengan yang seharusnya."14

Fenomena yang di maksudkan yaitu dimana pekerjaan yang di lakukannya tidak sesuai yang seharusnya yaitu seperti melakukan pekerjaan menjadi pengemis/pengamen dimana mereka sebenarnya masih mempunya fisik yang kuat untuk mencari pekerjaan yang layak, kemudian bekerja sebagai buruh bangunan wanita dimana wanita yang menjadi tulang punggung di keluarganya sehingga ia mengerjakan pekerjaan yang bukan seharusnya ia kerjakan, selanjutnya para pemuda yang melakukan pekerjaan yang meresahkan masyarakat (tindakan kriminal) seperti yang banyak terjadi yaitu begal yang khusunya yang terjadi di Kota Makassar ini, dimana pemuda melakukan tindakan seperti itu karena faktor lingkungan dan tidak terpenuhi kebutuhan ekonominya sehingga ia menjadikan pekerjaan itu untuk menutupi kebutuhannya.

Rasulullah menganjurkan kita untuk berusaha dan mencari nafkah yang halal dan thoyyib, tidak mengerjakan sesuatu yang haram, dan tidak dengan meminta-minta. Umat muslim diperintahkan untuk menghindari meminta minta kecuali orang tersebut mendapat musibah, terlilit utang dan kondisi tubuh yang sudah tidak memungkinkan untuk bekerja.

\footnotetext{
14Sartika (35 tahun). Warga. Wawancara Makassar 9 Januari 2018.
} 
Ada beberapa faktor munculnya kemiskinan yaitu pertama karena faktor kurangnya rejeki yang di berikan oleh Allah swt, selain itu ada juga faktor perlakuan dari masyarakat sendiri yang tidak ingin bekerja maksimal dan hanya ingin menerima bantuan dari pemerintah. Selanjutnya karena faktor kemalasan, dimana tidak adanya motivasi individual dari masyarakatnya untuk meningkatkan perekonomiannya. Kota Makassar merupakan sumber potensi pembangunan bahkan orang daerah banyak yang datang untuk mencari pekerjaan tapi karena masyarakatnya merasa cukup puas dan kesenangan sesaat dimana dia tidak mau untuk berusaha dan meningkatkan kemampuannya. ${ }^{15}$

Bekerja bukan sekedar untuk mencari nafkah guna memenuhi kebutuhan hidup secara material semata, namun bekerja juga dapat mengantarkan seseorang kepada kesuksesan dalam hidup dan kebutuhan. Sebaliknya, apabila seseorang menganggur maka mereka akan sering menghayal yang tidak-tidak dan akhirnya bisa menjurumuskan pada perbuatan yang kurang baik.

Perkembangan kasus geng motor di kota Makassar sangatlah menakutkan dan membuat resah warga kota Makassar, faktor kemalasan yang ada dalam diri mereka merupakan salah satu penyebab mereka tidak mau berusaha untuk mendapatkan pekerjaan yang lebih baik lagi sehingga ia tidak berpikir bahwa apa yang ia lakukan merupakan sesuatu yang salah dan tentu membahayakan dan meresahkan orang lain. Mereka hanya berpikir bagaimana cara mereka mendapatkan uang sehingga terpenuhi kebutuhanya. Dalam Islam hal tersebut dilarang sebagaimana dalam firman Allah QS. An-Nisaa' /4: 29

${ }^{15}$ La Heru (47 tahun). Seksi Jaminan Kesejahteraan Sosial. Wawancara Makassar 8 Januari 2018. 


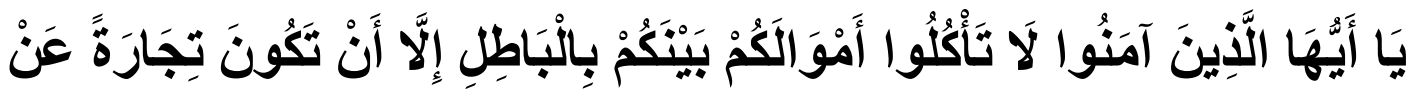

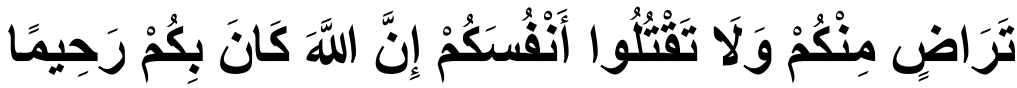

Terjemahnya:

Dan janganlah sebagian kamu memakan harta sebagian yang lain di antara kamu dengan jalan yang batil kecuali atas dasar suka sama suka di antara kamu". ${ }^{16}$

Dari ayat ini jelas bahwa manusia dilarang melakukan tindakan yang merugikan orang lain demi mendapatkan keuntungan. Termasuk dalam hal ini tindakan pembegalan yang dilakukan oleh sekelompok geng motor dengan merampas, mencuri dan merampok harta orang lain demi memperkaya diri sendiri.

Tujuan seseorang untuk bekerja bukan hanya untuk mendapatkan kekayaan materil saja tetapi juga keberkahan atas apa yang telah dikerjakan. Selain Geng motor, fenomena anak jalanan/pengemis bukanlah hal yang baru oleh bangsa ini khusunya di kota Makassar, fenomena ini sudah menggejala di masyarakat kita walaupun telah ada kebijakan pemerintah terkait anak jalanan dan anak putus sekolah di karenakan faktor ekonomi yang mengaruskan mereka untuk mencari pekerjaan juga agar terpenuhinya kebutuhan dalam keluarganya. Berbagai kesibukan mereka lakoni seperti meminta-minta atau sekedar menjual koran, tidak jarang juga ada yang keliling kompleks dengan bermodalkan buku-buku kecil yang berisi kumpulan-kumpulan doa untuk di jual, bahkan ada juga yang hanya bermodalkan selembar kertas yang sudah lusuh dan berlipat-lipat.

Dalam Islam, kemiskinan juga merupakan suatu ujian sebagaimana dalam QS. Al-Baqarah/ 2: 155

${ }^{16}$ Departemen Agama RI, Al-Qur'an dan Terjemah, h.43 


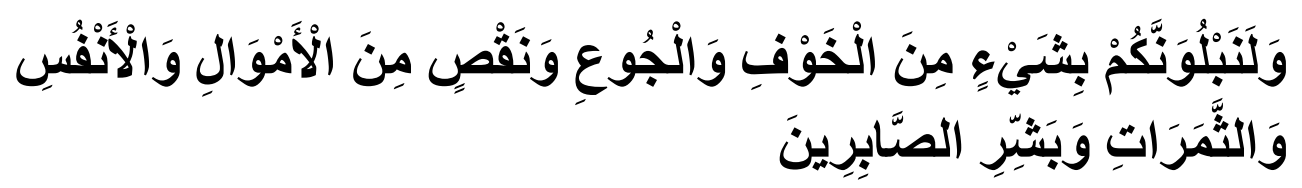

Terjemahnya:

Dan sungguh akan Kami berikan cobaan kepadamu, dengan sedikit ketakutan, kelaparan, kekurangan harta, jiwa dan buah-buahan. Dan berikanlah berita gembira kepada orang-orang yang sabar" ${ }^{17}$

Oleh sebab itu manusia diperintahkan untuk bekerja keras dan terus bersabar. Karena pada dasarnya setiap manusia mempunyai peluang untuk mendapatkan pekerjaan yang diusahakan oleh manusia, dimana setiap hambanya yang mau berusaha dan mau bekerja keras pasti akan mendapatkan rezeki darinya dan manusia dituntut untuk mau berusaha dan juga bersabar. Barangsiapa bersabar, maka Allah akan memberikan pahala baginya.

Sedangkan Pengemis yang terlahir dengan kurangnya anggota badan atau cacat. Sehingga membuat kesempatan bersekolah dan kerja menjadi terbatas karena lapangan pekerjaan memperkerjakan orang-orang yang kekurangan fisik sangatlah langkah maka dari itu orang yang cacat berpikir bagaimana cara ia mendapatkan uang, karena lumpuh ia memanfaatkan kekurangannya agar mendapatkan hibah dari orang-orang dan pasrah terhadap kekuranganya karena ia berpikir kekuranganku mendatangkan rezeki. Dalam Islam, hal tersebut tidak masalah, dengan catatan bahwa orang tersebut memang sudah dalam keadaan terhimpit dan sangat membutuhkan uluran tangan dan bantuan dari orang lain. Kalaupun tidak, orang tersebut bisa mencari keahlian untuk menghasilkan uang. Karena banyak juga dijumpai orang yang memiliki keterbatasan fisik tapi mereka mampu untuk menghasilkan uang seperti menjadi pelukis, pengrajin atau usaha lainnya sesuai dengan keterampilan yangyang mereka miliki.

\footnotetext{
17Departemen Agama RI, Al-Qur'an dan Terjemah, h.13.
} 


\section{Upaya Pemerintah Dalam Menanggulangi Kemiskinan di Kota Makassar}

Kemiskinan di kota Makassar ini merupakan masalah yang sangat penting untuk di atasi dalam rangka percepatan penanggulangan kemiskinan, maka dari itu peran pemerintah kota Makassar sangat di perlukan.

Dinas Sosial dalam hal ini sebagai bagian dari lembaga pemerintah kota Makassar yang berfokus pada pembangunan kesejahteraan sosial harusnya sangat berperan dalam pengentasan kemiskinan, antara lain melaksanakan kegiatan yang bertujuan untuk memberdayakan fakir miskin. Pemberdayaan fakir miskin merupakan salah satu upaya strategis nasional dalam mewujudkan sistem ekonomi kerakyatan yang berkeadilan sosial dan melindungi hak asasi manusia terutama dalam pemenuhan kebutuhan dasar manusia.

Menangani kemiskinan bukan hanya dari dinas sosial saja, dari dinas kesehatan juga perlu untuk menangani masalah kesehatan masyarakat, dari dinas pendidikan yang bertanggung jawab bagi anak sekolah yang tidak mampu dengan memberikan bantuan, orang miskin jika dilihat dari rumahnya yang bertanggung jawab yaitu dinas perumahan, dan dari BUMN sendiri ia memberikan bantuan elpiji gratis bagi masyarakat yang tidak mampu."18

Adapun beberapa tahap yang dilakukan pemerintah kota Makassar dalam menanggulangi kemiskinan dengan menerapkan beberapa program, antara lain menjaga stabilitas harga bahan kebutuhan pokok, mendorong pertumbuhan yang berpihak pada rakyat miskin, menyempurnakan dan memperluas cakupan program pembangunan berbasis masyarakat, meningkatkan akses masyarakat miskin kepada pelayanan dasar, membangun dan menyempurnakan sistem perlindungan sosial bagi masyarakat miskin.

${ }^{18}$ La Heru (47 tahun). Seksi Jaminan Kesejahteraan Sosial. Wawancara Makassar 8 Januari 2018. 
Beberapa tahap telah disebutkan agar jumlah kemiskinan di kota Makassar dapat tertanggulangi sedikit demi sedikit. Tahap pertama dengan menjaga stabilitas harga bahan kebutuhan pokok dapat dijalankan dalam suatu program yang bertujuan untuk menjamin daya beli masyarakat miskin atau keluarga miskin untuk memenuhi kebutuhan pokok terutama beras, tahap kedua dengan mendorong pertumbuhaan pihak pada rakyat miskin ini ditujukan agar masyarakat miskin diberikan kesempatan untuk membangun suatu usaha yang lebih luas dengan cara bertahap, tahap ketiga menyempurnakan dan memperluas cakupannya dalam membangun masyarakat untuk meningkatkan sinergi dan optimalisasi di kawasan perkotaan dalam ruang lingkup kemiskinan untuk memperkuat penyediaan dukungan dalam pengembangan berusaha bagi penduduk miskin, kemudian tahap keempat yaitu akses masyarakat harus ditingkatkan pelayanan dasarnya untuk lebih fokus dalam meningkatkan pendidikan, kesehatan, dan prasarana dasarnya, untuk ditahap akhir kelima membangun dan menyempurnakan sistem perlindungan sosial untuk masyarakat miskin tersebut dalam menghadapi guncangan sosial dan ekonomi. ${ }^{19}$

Adapun beberapa upaya telah di laksanakan oleh pemerintah untuk memberikan bantuan kepada masyarakat miskin yang terjadi di kota Makassar yaitu membiayai keluarga bagi yang mempunyai anak sekolah yang tidak memiliki dana untuk menempuh pendidikan, program kesehatan bagi ibu hamil/balita yang akan dibiayai oleh pemerintah bagi orang yang tidak mampu, membiayai kehidupan lansia yang berusia diatas 70 tahun dengan memberikan bantuan kepadanya, memberikan bantuan untuk disabilitasi berat/cacat berat yang dimana semua komponen atau penyakit yang membuat

${ }^{19}$ La Heru (47 tahun). Seksi Jaminan Kesejahteraan Sosial. Wawancara Makassar 8 Januari 2018. 
orang itu tidak bisa berdaya apa-apa, contoh lumpuh seluruh badan. ${ }^{20}$ Penangulangan kemiskinan dalam Islam dan mewujudkan kesejahtaraan bagi rakyat memang sudah merupakan tugas dari pemerintah. Abu yusuf, salah satu pembahasan dalam kitab al-kharaj menguraikan tentang negara dan aktifitas ekonomi dimana beliau berpandapat bahwa tugas utama pemeritah adalah mewujudkan dan menjamin kesejahteraan rakyat, memenuhi kebutuhan rakyat serta mengembangkan berbagai kebijakan yang pro rakyat seperti membangun proyek yang berorientasi pada kesejahteraan umum. Dalam hal ini, beliau terilhami oleh pernyataan khalifah Umar bin Khattab bahwa sebaikbaik penguasa adalah mereka yang memerintah demi kemakmuran rakyatnya dan seburuk-buruk penguasa adalah mereka memerintah tetapi rakyatnya mengalami kesulitan. ${ }^{21}$

Zakat juga mempunyai kedudukan yang sangat penting dalam menanggulangi kemiskinan. Zakat adalah poros dan pusat keuangan Negara Islam yang mana memiliki implikasi transformasi yang jelas dalam bidang moral, sosial, dan ekonomi. Dalam bidang moral, zakat mengikis habis keserakahan orang kaya. Dalam bidang sosial, zakat bersifat sebagai instrumen khas dalam Islam menghapuskan kemiskinan mayarakat dengan menyadarkan orang kaya akan bertanggung jawab sosial yang berada di pundaknya. Dalam bidang ekonomi, zakat merupakan sumbangan wajib yang memiliki nilai penting bagi perbendaharaan Negara Islam.

${ }^{20}$ La Heru (47 tahun). Seksi Jaminan Kesejahteraan Sosial. Wawancara Makassar 8 Januari 2018.

21 Sumar'in, Ekonomi Islam: Sebuah Pendekatan Ekonomi Mikro Perspektif ekonomi Islam (Yogyakarta: Graha Ilmu. 2013), h. 38. 


\section{KESIMPULAN}

Urbanisasi merupakan salah satu penyebab bertambahnya jumlah penduduk miskin di perkotaan. Bertambahnya jumlah penduduk di kota Makassar yang tidak dibarengi dengan peningkatan lapangan pekerjaan sehingga menimbulkan fenomena fenomena seperti anak jalanan, pengemis dan geng motor di perkotaan. Dalam Islam, Rasulullah menganjurkan kita untuk berusaha dan mencari nafkah yang halal dan thoyyib, tidak mengerjakan sesuatu yang haram, dan tidak dengan meminta-minta. Umat muslim diperintahkan untuk menghidari meminta minta kecuali orang tersebut mendapat musibah, terlilit utang dan kondisi tubuh yang sudah tidak memungkinkan untuk bekerja.

Penanggulangan fenomena kemiskinan pemerintah kota Makassar memberikan suatu upaya dengan menjaga stabilitas harga bahan kebutuhan pokok, mendorong pertumbuhan yang berpihak pada rakyat miskin, menyempurnakan dan memperluas cakupan program pembangunan berbasis masyarakat, meningkatkan akses masyarakat miskin kepada pelayanan dasar, membangun dan menyempurnakan sistem perlindungan sosial bagi masyarakat miskin. 


\section{DAFTAR PUSTAKA}

Aath-Thawil. Kemiskinan dan Keterbelakangan di Negara-Negara Muslim diterjemah Muhammad Bagi. ; cet .1. Bandung : Mizan, 1985

Ahmad, Abu. Ilmu Sosial Dasar .Jakarta: Renika Cipta. 2003.

Basri, Faisal. Perekonomian Indonesia. Jakarta : Erlangga. 2002.

Berita Sulsel, Data Penduduk Miskin Makassar 2015-2017, http://beritasulsel.com/2017/03/31/data-jumlah-penduduk-makassar-tahun-2015hingga-2017/ (26 Oktober 2017)

Departemen Agama RI. Al-quran dan Terjemah. Jakarta : WALI. 2013.

Efendi, Tadjuddin Noer. Sumber Daya Manusia, Peluang Kerja dan Kemiskinan. Yogyakarta : Pustaka Pelajar. 1993.

Huda, Nurul. dkk. Ekonomi Pembangunan Islam. Jakarta: Prenadamedia Group. 2015.

Meleong,Lexy J. Metodologi Penelitian Kualitatif. Bandung : PT Remaja Rosdakarya, 1994.

Setiadi,Elly M., Usman Kolip, Pengantar Sosiologi, Jakarta : Prenamedia Group, 2011.

Sudarwati,Nanik. Kebijakan Pengentasan Kemiskinan Mengurangi Pengangguran Kemiskinan. Malang : Intimedia. 2009.

Sumar'in, Ekonomi Islam: Sebuah Pendekatan Ekonomi Mikro Perspektif ekonomi Islam ,Yogyakarta: Graha Ilmu. 2013.

Suparlan,Parsudi. Kemiskinan di Perkotaan. Jakarta : Yayasan Obor Indonesia. 1995. Suwarsono,Sri Edi. Sekitar Kemiskinan dan Keadilan. Jakarta: Cendikiawan Tentang

Islam UI Press. 2007. 